\title{
Obraz člověka v Gaudium et spes a jeho praktický výklad papežem Františkem János Wildmann
}

\section{Co je člověk?}

II. vatikánský koncil vícekrát zdůrazňuje, že církev nestojí proti světu, ale ve světě. Již první, tak často citovaná věta konstituce Gaudium et spes je zároveň vyznáním a programem: „Radost a naděje, smutek a úzkost lidí naší doby, zvláště chudých a všech, kteří nějak trpí, je i radostí a nadějí, smutkem a úzkostí Kristových učedníků, a není nic opravdu lidského, co by nenašlo v jejich srdci odezvu. (...) Proto také toto společenství cítí, že je opravdu těsně spjato s lidstvem a jeho dějinami“.1

V dalším článku se proto koncil obrací „nejen k synům církve a k těm, kdo vzývají Kristovo jméno, ale ke všem lidem. Všem chce vyložit, jak chápe př́tomnost a působení církve v dnešním světě. “2 Následně ohlašuje svou „sounáležitost, úctu a lásku k celé lidské rodině, do níž je začleněn, (a nemůže ji) dokázat výmluvněji, než že s ní o takových problémech začne rozhovor, přinese do něho světlo čerpané z evangelia a dá lidstvu k dispozici síly potřebné ke spáse, které církev pod vedením Ducha svatého dostává od svého zakladatele. Jde totiž o záchranu lidské osoby a obnovu lidské společnosti. Těžištěm našeho výkladu bude tedy člověk, a to člověk ve své jednotě a úplnosti, s tělem i duší, srdcem i svědomím, myslí i vůlí. “"

Již v poslední větě jsou zmíněny některé důležité aspekty obrazu člověka na koncilu, které byly později podrobněji vysvětleny. Nejdříve však byla zdůrazněna úzká spojitost církve se světem. V článku 11 je uvedeno, že „Boží lid a lidstvo, jehož je Boží lid součástí, si navzájem prokazují služby, takže se poslání církve prokáže jako náboženské a právě tím i svrchovaně lidské“. ${ }^{4}$ To znamená, že humanita a křestanská víra se navzájem nejen nevylučují, ale že pravá humanita žije $\mathrm{z}$ křestanské víry. $\mathrm{V}$ každém př́padě spočívá základ dialogu a spolupráce se všemi lidmi v humanitě, ke které se hlásí církev a všichni lidé dobré vůle, včetně ateistů. Humanita je proto prakticky prubíŕským kamenem obrazu člověka, na kterém se bud’ osvědčí, nebo ztroskotá.

Název první kapitoly první části konstituce zní: „Důstojnost lidské osoby“. Již první věta zdůrazňuje spolupráci mezi věřícími a nevěŕícími, že „věřící i nevěřící jednomyslně soudí, že všechno 
na světě má být zaměřeno $k$ člověku jako svému středu a vyvrcholení. Co však je člověk? “5 - ptá se koncil. Na tuto otázku je mnoho, částečně rozporuplných odpovědí. Církev může „poučena Božím zjevením na ně dát odpověd popisující pravý stav člověka, vysvětlující jeho slabosti a zároveň dávající možnost uznat jeho pravou důstojnost a povolání“. Místo aby se zaplétal do teologických a filosofických výkladů, odkazuje koncilní text na učení Písma svatého, podle něhož „člověk byl stvořen ,k Božímu obrazu', dostal schopnost poznávat a milovat svého Stvořitele“. ${ }^{\text {“ }}$

Nevysvětluje se zde, co to znamená „být stvořen k Božímu obrazu“, ale podle učení církve je tím myšlena „duše“ jako duševní princip života v člověku, který ho tak činí nikoliv něčím, nýbrž někým. V tom spočívá důstojnost osoby. Proto ho Bůh učinil „pánem nad veškerým pozemským tvorstvem, aby mu vládl a užíval ho k Boží slávěc. Další charakteristika člověka je, že ho nenechal samotného, ale stvořil ho jako muže a ženu (Gn 1,27). „Jejich spojením vzniká první forma osobního společenství. Člověk je totiž v jádru své přirozenosti bytost společenská a bez vztahu k ostatním nemůže žít ani rozvíjet své vlohy.“7

V dalším článku se hovoří o hříšnosti člověka. Člověk zneužívá svoji svobodu a „je nakloněn i ke zlému a zapleten do mnoha špatností“. Když se člověk zdráhá „uznat Boha jako svůj původ“, má to důsledky na mnoha rovinách: míjí tak „zaměření $\mathrm{k}$ svému poslednímu cíli i celý rád vztahů vůči sobě, jiným lidem a všem stvořeným věcem. Proto je člověk sám v sobě rozdělen. To je také důvod, proč se nám celý lidský život, individuální i kolektivní, jeví jako dramatický zápas mezi dobrem a zlem, mezi světlem a tmou. ${ }^{\text {"8 }}$

Ohledně stavu člověka to znamená, že „je tělem a duší“. Ty oba od sebe nejde oddělit. Tím koncil odmítá gnosticko-manichejské dualistické pojetí těla a duše. Člověk je proto „povinen považovat své tělo za dobré a hodné úcty, poněvadž bylo stvořeno Bohem a posledního dne má být vzkř́í̌eno“. Na druhé straně se ale člověk nemýlí, „když se nepovažuje za pouhou část prŕrody nebo za bezejmennou jednotku lidské společnosti“, ale uznává, „že má duchovou a nesmrtelnou duši“.

V dalších článcích se pojednává o třech hlavních znacích lidského ducha, kterými jsou rozum, svědomí a svoboda. Člověk „svým rozumem převyšuje vesmír věcí“. Vyvinul „empirické vědy, techniku, duchové obory a umění“. Kromě toho má schopnost „nacházet hlubší pravdu“, a „postihnout rozumové jádro skutečnosti“. Naplněním rozumu je ale moudrost, „která lidskou mysl jemně přitahuje $\mathrm{k}$ hledání a milování pravdy a dobra. Prostoupí-li člověka, přivádí ho prostřednictvím věcí viditelného světa $\mathrm{k}$ neviditelnému “. ${ }^{10}$ Koncilní teolog Josef Ratzinger $\mathrm{k}$ tomu podotýká, že věda sama o sobě člověka nemůže humanizovat, $\mathrm{k}$ tomu potřebuje moudrost. ${ }^{11}$

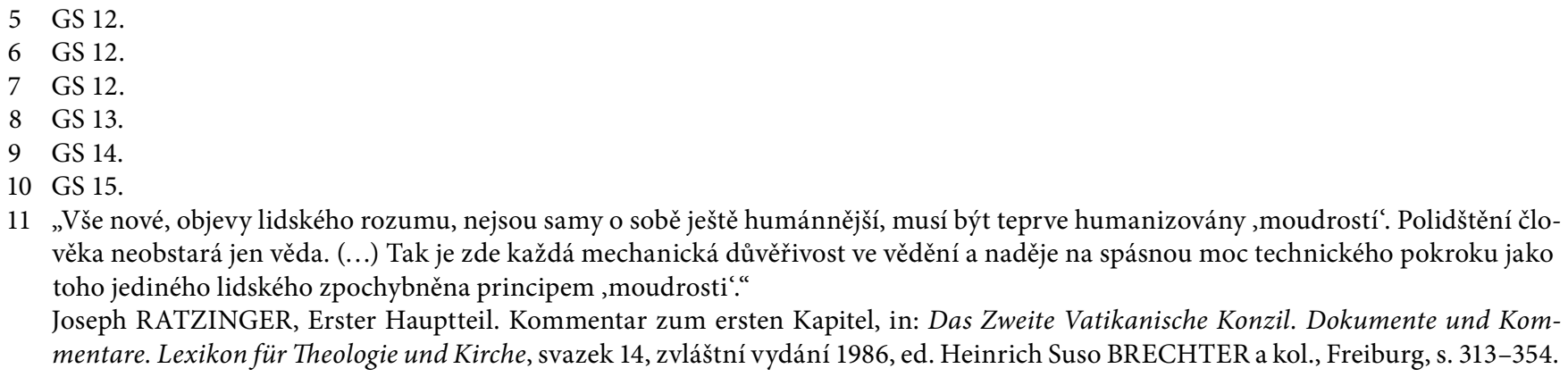

11 „Vše nové, objevy lidského rozumu, nejsou samy o sobě ještě humánnější, musí být teprve humanizovány ,moudrostí. Polidštění člověka neobstará jen věda. (...) Tak je zde každá mechanická důvěrivost ve vědění a naděje na spásnou moc technického pokroku jako toho jediného lidského zpochybněna principem ,moudrosti“““

Joseph RATZINGER, Erster Hauptteil. Kommentar zum ersten Kapitel, in: Das Zweite Vatikanische Konzil. Dokumente und Kommentare. Lexikon für Theologie und Kirche, svazek 14, zvláštní vydání 1986, ed. Heinrich Suso BRECHTER a kol., Freiburg, s. 313-354. 
Dalším podstatným znakem lidského ducha je svědomí „Jeho hlas ho stále vybízí, aby miloval a konal dobro a vyhýbal se zlu, a když je třeba, promlouvá k sluchu jeho srdce: toto dělej, tamto nedělej." Naproti čistě sociálnímu chápání svědomí zdůrazňuje koncil jeho transcendentní charakter. „Nebơ člověk má ve svém srdci zákon vepsaný Bohem; v poslušnosti vůči němu spočívá jeho důstojnost a podle něho bude souzen. Svědomí je nejtajnější stř̌ed a svatyně člověka; v ní je sám s Bohem, jehož hlas mu zaznívá v nitru.“ A i když „se svědomí vlivem nepřekonatelné neznalosti mýlí, neztrácí tím svou důstojnost. ${ }^{12}$ Ratzinger připomíná, že svědomí je nadřazeno i církevní autoritě. ${ }^{13}$

Třetí hlavní znak lidského ducha je svoboda. Koncil neposuzuje filosofické, psychologické, sociologické nebo kulturní aspekty, ačkoliv by to pro jeho správné chápání bylo nutné, protože lidská svoboda není absolutní, ale je v mnohých ohledech omezena. Koncilním otcům však nešlo o komplexní uvedení problému, nýbrž o to, aby se svobodou souhlasili z pozice víry, nebở „člověk se může přiklonit $\mathrm{k}$ dobru jen svobodně“, i když se člověk často o svou svobodu zasazuje „špatným způsobem, jako o možnost dělat cokoli, i zlo, jen když to přináší potěšení. (...) Důstojnost člověka tedy vyžaduje, aby jednal podle vědomé a svobodné volby, to znamená hýbán a podněcován z nitra osobním přesvědčením, a ne ze slepého vnitřního popudu nebo pouze $\mathrm{z}$ vnějš́ho donucení. Této důstojnosti člověk dosahuje tím, že se osvobozuje z každého zajetí vášní, směřuje k svému cíli svobodnou volbou dobra." ${ }^{14}$

V dalším článku je ta největši hádanka lidského bytí, smrt. „Člověka netrápí jenom bolest a postupný tělesný úpadek, ale také - ba více - strach z trvalého zániku." Bůh však volá člověka a Kristus mu otevírá cestu „k věčnému společenství neporušitelného božského života“. ${ }^{15}$ Pak následují tř̌i články o ateismu; o jejich praktickém významu bude ještě pojednáno.

První kapitola o důstojnosti lidské osoby je zakončena pojednáním o Kristu, nebơ „tajemství člověka se opravdu vyjasňuje jen v tajemství vtěleného Slova“; Kristus, „nový Adam, právě zjevením tajemství Otce a jeho lásky plně odhaluje člověka jemu samému a dává mu poznat vznešenost jeho povoláníc. To znamená, že teologie, $v$ jejímž středu je Kristus, je zároveň antropologií, učením o člověku. „Vždyt svým vtělením se jistým způsobem spojil s každým člověkem, on sám, Boží Syn. Lidskýma rukama pracoval, lidskou myslí přemýšlel, lidskou vůlí jednal, lidským srdcem miloval. ${ }^{{ }^{16}}$ Křestané mají jako on bojovat proti zlu, snášet smrt, avšak také mít naději, že kráčí vstříc vzkř́íšení. „To neplatí jen pro křestany, ale pro všechny lidi dobré vůle, v jejichž srdci neviditelně působí milost. ${ }^{{ }^{117}}$

\section{Koncilní obraz člověka a ateismus}

Vrat’me se nyní ke dříve zmíněným třem článkům o ateismu. $Z$ dosavadních úvah je jasné, že chápání člověka a pravá humanita jsou podle koncilu založeny na křestanské víre. $Z$ toho můžeme vyvozovat, že církev má jiné pojetí člověka a humanity a odmítá ta pojetí, která vidí člověka zjednodušeně a brání mu v jeho rozvíjení. To platí především o ateismu, který „toto hluboké životní spojení s Bohem vůbec nechápe nebo je výslovně odmítá “. ${ }^{18}$

13 „Nad papežem jako vyjádřením závazného nároku církevní autority stojí vlastní svědomí, které je třeba poslouchat především, je-li to potřeba, i proti požadavkům církevní autority.“ Joseph RATZINGER, Erster Hauptteil. Kommentar zum ersten Kapitel, s. 328. 
V původním textu nebyl tento úsek zamýšlen, ale v generální debatě v ř́innu 1964 se o něm diskutovalo. Mnoho koncilních otců usilovalo o odsouzení tohoto bezbožného světového názoru, zvláště v marxistické variantě. Dopadlo to však jinak a ke kapitole o důstojnosti člověka byly připojeny ještě tři obsáhlé texty o ateismu. Nebudeme zde o nich pojednávat podrobně, je však třeba vyzdvihnout jejich praktický význam.

Po krátkém představení různých forem ateismu se text zabývá př́činami, „mezi které je třeba počítat i kritickou reakci proti náboženství, v některých zemích zvláště proti náboženství křestanskému. Proto mohou mít nemalý podíl na vzniku ateismu věřící tím, že zanedbávají náboženskou výchovu, zkresleně podávají nauku a mají nedostatky ve svém náboženském, mravním a sociálním životě; o nich platí, že pravou tvář Boha a náboženství spíše zastírají, než ukazují." Kromě toho koncil uznává, že ateismus může mít veskrze humanitární motivy, protože „nezř́dka vzniká $\mathrm{Z}$ vášnivého protestu proti zlu ve světě“ ${ }^{19}$

V článku 20 se kromě existencialismu pojednává o marxistickém ateismu, i když se tak explicitně nenazývá. Přes opakované připomínky stovek koncilních otců, aby byl jasně odsouzen slovy, jak se to $\mathrm{v}$ minulosti častěji stalo, $\mathrm{k}$ tomu nebyla většina koncilu ochotna - $\mathrm{k}$ velkému zklamání mnoha křestanů $\mathrm{v}$ bývalých socialistických zemích. To však nelze považovat za odchylku od dosavadní církevní pozice, spíše se ukazují jiné akcenty koncilu: Místo hrozeb a odsouzení vůči druhým by se měla církev sama sebekriticky zpytovat. Ve svém komentári píše Josef Ratzinger o tom, že „církev si musí uvědomit svůj vlastní podíl na celé otázce marxismu, na nedostatečnosti svého vlastního humanismu. (...) Zde se získal postoj. (...) Zpytování svědomí, které vychází z tohoto textu, (...) poskytne v budoucích konfrontacích více možností ukázat směr, než jak by to mohlo poskytnout provedené znázornění komunismu a jeho obnovená odsouzení. “20

To nebrání koncilu, „se vší rozhodností (...) odmítnout ty to zhoubné nauky a činy, které (...) zbavují člověka jeho vrozené velikosti. (...) Církev je přesvědčena, že uznání Boha není v rozporu s důstojností člověka, nebơ tato důstojnost má základ a dovršení právě v Bohu. “. ${ }^{21}$ Místem setkání křestanské víry a ateismu je zodpovědnost za tento svět. „Církev, přestože ateismus naprosto odmítá, přece upřímně vyznává, že $\mathrm{k}$ správnému budování tohoto světa musí přispívat všichni lidé, kteří $\mathrm{v}$ něm společně žijí, věřící i nevěřící. To se ovšem nemůže stát bez upřímné a rozumné výměny názorů.“. Tak se poprvé v církevním dokumentu objevuje požadavek dialogu a spolupráce s ateisty.

\section{Koncilní obraz člověka a náboženská svoboda}

Další př́íklad nám jasně ukazuje, jak rozhodně se koncil cítil být povinován tomuto obrazu člověka, i když to znamenalo jisté korektury dosavadní pozice církve. Jde o Dignitatis humanae, prohlášení o náboženské svobodě.

19 GS 19.

20 Celá poslední věta zní: „Zpytování svědomí, které vychází z tohoto textu (z toho, co neříká, ještě více než z toho, co říká), otřesení sebeidentifikací křestanství se západním světem a pobídka vidět jako křestanský úkol utrpení chudých, nouzi lidí zbavených práv, protože křestanství se musí legitimovat jako humanismus, aby mohlo obstát - toto zpytování svědomí poskytne v budoucích konfrontacích více možností ukázat směr, než jak by to mohla poskytnout provedená znázornění komunismu a jeho obnovená odsouzení.“ Joseph RATZINGER, Erster Hauptteil. Kommentar zum ersten Kapitel, s. 343.

21 „Jestliže naopak tento božský základ a naděje ve věčný život chybí, je důstojnost člověka, jak se dnes můžeme často přesvědčit, vážně poškozena a záhady života a smrti, viny a bolesti zůstávají bez řešení, takže lidé nezř́ídka upadají do beznaděje. Každý člověk zatím zůstává sám sobě nerozřešenou otázkou, kterou si nejasně uvědomuje. V určitých okamžicích, hlavně při závažnějších životních událostech, jí nikdo nemůže zcela uniknout." GS 21.

22 GS 21. 
Dřívější učení církve říkalo, že práva má jen pravda, nikdy omyl. Protože náboženská pravda je identická s učením katolické církve, měla nárok na neomezenou svobodu. Papežové Řehoř XVI. a Pius IX. označovali ještě svobodu svědomí za šílenství. ${ }^{23}$ Lev XIII. jí nechal práva jen tehdy, když odpovídala vůli a přikázáním Božím podle učení katolické církve. ${ }^{44}$ Také Pius XII. prohlásil: „To, co neodpovídá pravdě a normě morálky, nemá objektivně právo na existenci, ani na propagandu a akci. ${ }^{\text {“'5 }}$ To znamenalo pro svobodu náboženství toto: Jestliže byla většina společnosti katolická, pak měl stát katolíkům zaručit plnou náboženskou svobodu. Všechna ostatní náboženská společenství neměla nárok na to, aby jim nebylo bráněno v provozování jejich náboženství, avšak stát je mohl $\mathrm{v}$ zájmu obecného blaha tolerovat. $\mathrm{V}$ opačném př́padě, když většina společnosti nebyla katolická, měl stát zaručit katolíkům podle přirozeného práva plnou náboženskou svobodu.

Toto pojetí bylo před koncilem stále méně udržitelné. Ve všeobecné deklaraci lidských práv OSN z r. 1948 se v článku 18 praví: „Každá osoba má právo na svobodu myšlení, svědomí a náboženství. “26 Papež Jan XXIII., který svolal II. vatikánský koncil, stanovil ve své encyklice Pacem in terris (1963) nový směr: Oslovil všechny lidi dobré vůle a prohlásil za lidské právo mimo jiné také právo „uctívat Boha podle svědomí a moci soukromě i veřejně své náboženství vyznávat“. ${ }^{27}$

Přesto nebylo schválení deklarace o náboženské svobodně na koncilu snadnou záležitostí. Původní text byl sedmkrát přepracován a i poslední verze narazila na prudký odpor. Především biskupové z mnoha katolických zemí hájili privilegia katolíků. Jestliže má blud stejná práva jako pravda, povede to prý k indiferentismu - to byl jeden z jejich argumentů. Další výhrada byla, že nové pojetí koncilu odporovalo dosavadnímu učení katolické církve. Přitom však zapomínali na to, že dějinnost církve obsahuje i dějinnost učení, tzn. že existuje vývoj v učení a dogmatech. Koncil se proto obrací na „posvátnou církevní tradici a nauku a vynáší z nich stále něco nového, co je však v souladu s tím starým“ ${ }^{28}$

Hlavní otázka diskuse byla: Co má prioritu, pravda, nebo svoboda? Smí se kvůli ochraně katolické pravdy omezit svoboda svědomí ve společnosti? A obráceně: Smí se kvưli garanci svobody svědomí jiných - i těch, kteří jsou v bludu - ohrozit katolická pravda? Koncilní většina byla toho názoru, že vztah lidí a víry je metafyzická, dogmatická, př́ípadně morální otázka, ale že to není právní vztah. Právní vztah může být jenom mezi dvěma osobami, tzn. že jen lidé si mohou navzájem uznávat právo na náboženskou svobodu, nezávisle na obsahu víry.

V předmluvě k Dignitatis humanae se koncil hlásí ohledně pravdy k dosavadnímu učení církve: „Věříme, že toto jediné pravé náboženství je uskutečněno v katolické a apoštolské církvi, které Pán Ježíš svěřil úkol přinášet je ke všem lidem. “" ${ }^{29}$ Toto stanovisko církve se nezměnilo vǔči pravdě, nýbrž vưči svobodě člověka ve společnosti, nebot nadále existují povinnosti hledat pravdu, „které se dotýkají lidského svědomí a zavazují je a pravda nevznáší svůj nárok jinak než silou pravdy samé,

23 PIUS IX., Quanta cura (1864), německé vydání: Köln, 1865.

24 LEO XIII., Libertas praestantissimum (1988), německé vydání: Essen, 1903.

25 PIUS XII., promluva dne 6. prosince 1953.

26 ○) Vereinte Nationen, Resolution der Generalversammlung 217 A (III): Allgemeine Erklärung der Menschenrechte (on-line), dostupné na: http://www.un.org/depts/german/menschenrechte/aemr.pdf, citováno dne 20. 11. 2015.

27 (C) JOHANNES XXIII., Pacem in terris (1963), čl. 14 (on-line), dostupné na: http://198.62.75.1/www1/overkott/pacem.htm, citováno dne 20. 11. 2015.

28 Die Dokumente des Zweiten Vatikanischen Konzils, Freiburg im Breisgau: Herder, 2012. Erklärung Dignitatis humanae, čl. 1. Dále pouze $\mathrm{DH}$ a číslo príslušného oddílu.

29 DH 1. 
která proniká do lidské mysli jemně a spolu mocně“.$^{30}$ Náboženská svoboda znamená „svobodu od nátlaku v občanské společnosti“."31

V poslední fázi koncilu měli i původní odpůrci sklon uznat náboženskou svobodu jako pozitivní občanské právo, jako výsledek dějinného vývoje, který má stát garantovat $\mathrm{v}$ zájmu obecného blaha. Většina koncilních otců však tuto úvahu rozhodně odmítala a obracela se k obrazu člověka v pastorální konstituci. Právo na náboženskou svobodu není totiž založeno na státním zákonodárství, nýbrž skutečně „na důstojnosti lidské osoby, jak nám ji dává poznat i zjevené Boží slovo i sám rozum. Toto právo lidské osoby na náboženskou svobodu má být uznáno v právním uspořádání společnosti tak, aby se stalo občanským právem. ${ }^{\text {“32 }}$

Svoboda náboženství je v deklaraci pojednána jako občanské právo, avšak někteří koncilní otcové chtěli připojit úsek, který by se zabýval důstojností a svobodou člověka uvnitř církve. Jejich přání bylo zamítnuto, protože by to byl cizí prvek $\mathrm{v}$ deklaraci a dotýkal by se velmi citlivých pastoračních otázek, a tak by nebylo možné dosáhnout většiny ke schválení dokumentu. I bez tohoto dodatku je jasné, jak říká Yves Congar, že důstojnost osoby se všemi důsledky by měla mít i v církvi svou plnou platnost. ${ }^{33}$

\section{Praktický výklad koncilního obrazu člověka}

Teoretický konstrukt koncilního obrazu člověka byl v katolické církvi v posledních 50 letech do značné míry přijat. Teologické zdůvodnění důstojnosti lidské osoby se rovněž nezpochybňuje stejně jako její podstatné znaky, jako je rozum, svědomí a svoboda. $V$ čem se však církevní názory rozcházejí, je praktický výklad tohoto obrazu člověka, především souvislost mezi vírou a humanitou.

Jedni ř́ikají - podle koncilu -, že humanita je praktickým prubiřským kamenem křestanské víry. Umistují ji ve světě, považují ji za partnera, hledají s ní dialog, mohou být i sebekritičtí, zasazují se o lepší svět, zvláště pro chudé a utiskované. Pro jiné je však důležitější vznešená, neporušená církev, která se vymezuje, která je vůči světu často neprátelská, která poučuje a odsuzuje. Jistě by bylo možné pro obě pozice uvést mnoho př́ikladů z uplynulých 50 let či z naší současnosti.

A je to právě papež František, který se s obdivuhodnou důsledností orientuje podle koncilního obrazu člověka. Při své cestě na Kubu v jednom kázání řekl, že být Božím dítětem propůjčuje člověku důstojnost, která je mimo každé společenské hodnocení. Ježíš je v tomto postoji k člověku prŕkladem a zve nás, „abychom krok za krokem překonali své předsudky“, a tak způsobili změny. ${ }^{34}$ Jestliže jsou ohroženy základní hodnoty, jako je lidská důstojnost a obecné dobro, „je zapotrrebí prorockého hlasu“ a církev musí stále zcela „zřetelně poukazovat na zásadní hodnoty lidské existence," píše v článcích 218 a 241 své encykliky Evangelii gaudium.

$30 \mathrm{DH} 1$.

31 DH 1. V článku 2 se vysvětluje tato svoboda od nátlaku: „Tato svoboda záleží v tom, že všichni lidé musí být prosti nátlaku jak ze strany jednotlivců, tak ze strany společenských skupin a jakékoli lidské moci, takže nikdo ani nesmí být donucován jednat v oblasti náboženství proti svému svědomí, ani mu nesmí být zabraňováno jednat podle svého svědomí soukromě i veřejně, bud’ sám nebo spolu s jinými, v náležitých mezích.“ DH 2.

$32 \mathrm{DH} 2$.

33 Yves CONGAR, Einleitung, in: Die Konzilserklärung Über die Religionsfreiheit, ed. Jérome HAMER - Yves CONGAR, Paderborn: Verlag Bonifacius-Druckerei, 1967, s. 15-19, zde s. 18.

34 Kathpress 21. 09. 2015. 
V jeho promluvách a textech najdeme mnoho př́kladů toho, že u určitých témat oslovuje „všechny lidi dobré vưle“ i takové, kteř́ odmítají „ideu Stvořitele anebo ji považují za irelevantni““ ${ }^{35}$ Avšak i s nimi je možný produktivní dialog a spolupráce. Na Kubě zmínil papež př́klad komunistických, židovských a katolických studentů v Buenos Aires, kteří se spojili, aby společně postavili centrum mládeže. To ukazuje, že společnost, která je schopna uzavírat společenská přátelství, má budoucnost. ${ }^{36} \mathrm{~V}$ encyklice Evangelii gaudium věnuje celou podkapitolu společenskému začleňování chudých. „Z naší víry v Krista, který se stal chudým a vždy byl nablízku chudým a lidem na okraji, vyplývá naše starost o integrální rozvoj těch, kdo jsou ve společnosti nejopuštěnějšsi“ ${ }^{\prime \prime}$ - zní již v první části této podkapitoly. ${ }^{37}$ „Opce pro chudé je pro církev kategorií spís teologickou než kulturní, sociologickou, politickou či filozofickou. Bůh jim prokazuje ,svoje první milosrdenství. ${ }^{\prime \prime 38}$

Jen tyto věty možná neukazují ještě zcela zřetelně, s jakými důsledky je František vázán koncilním obrazem člověka. To se ukáže teprve tehdy, když je konkrétní a zaujímá postoj v citlivých otázkách, např. v problematice uprchlíků. Ve zmíněné podkapitole Evangelii gaudium píše: „Zvláštní výzvu pro mne představují migranti, protože jsem pastýřem církve bez hranic, která se cítí být matkou všech. Vybízím proto země k velkorysé otevřenosti, která namísto strachu ze zničení místní identity bude schopna vytvářet nové kulturní syntézy. ${ }^{{ } 39}$

V Laudato si' se nezasazuje jen o politicky pronásledované, ale také o uprchlíky kvůli životnímu prostředí, kteří bývají spiše označováni za uprchlíky ekonomické: „Tragicky se zvyšuje počet migrantů, kteří utíkají před bídou umocněnou devastací životního prostředí, nedostává se jim statutu uprchlíků podle mezinárodních konvencí a nesou tíži vlastního života zbaveného jakýchkoli ochranných norem." Stěžuje si dramatickými slovy na „všeobecnou lhostejnost" vůči těmto tragédiím, které se dějí právě nyní v určitých částech světa. „Chybějící reakce na tato dramata našich bratří a sester je znamením ztráty smyslu pro odpovědnost za naše bližní, na kterém stojí každá civilizovaná společnost. ${ }^{40}$

Mnozí z nás si ještě pamatují jeho cestu na Lampedusu před dvěma lety a na jeho dramatická slova ohledně uprchlíků, utonulých v moři. „Tito naši bratři a sestry se chtěli dostat $\mathrm{z}$ těžké situace a nalézt trochu klidu a pokoje. Hledali lepší místo pro sebe a své rodiny, avšak nalezli smrt. A jak často nenaleznou pochopení, přijetí, ani solidaritu. A také jejich hlas volá k Bohu!“, řekl s odkazem na Boží otázku Kainovi poté, co zabil svého bratra. Kdo je zodpovědný? „Dnes se ve světě za to nikdo necítí zodpovědný; ztratili jsme smysl pro sourozeneckou zodpovědnost." Stěžuje si na "globalizaci lhostejnosti“".

Také v tomto roce, kdy se již zdá, že celá problematika uprchlíků se vymkla kontrole, nebojí se zasazovat se za tyto lidi, některým z nich poskytnout př́stř̌eši ve Vatikánu a vyzývat farnosti, náboženská společenství či kláštery v Evropě, aby každý z nich přijal jednu rodinu. To by bylo konkrétní gesto solidarity a křestanské bliženecké lásky k nadcházejícímu roku milosrdenství, řekl.

35 FRANZISKUS, Laudato si’, Freiburg im Breisgau: Herder, 2015, čl. 62. Dále pouze LS a číslo příslušného oddílu.

37 FRANZISKUS, Die Freude des Evangeliums: Das Apostolische Schreiben „Evangelii gaudium“ über die Verkündigung des Evangeliums in der Welt von heute, Freiburg im Breisgau: Herder, 2014, čl. 186. Dále pouze EG a číslo příslušného oddílu.

38 EG 198.

39 EG 210.

40 LS 25.

41 (C) FRANZISKUS, Papstpredigt auf Lampedusa: „Wo ist dein Bruder?“ (on-line), dostupné na: http://de.radiovaticana.va/storico/2013/07/08/papstpredigt_auf_lampedusa_\%E2\%80\%9Ewo_ist_dein_bruder\%E2\%80\%9C/ted-708497, citováno dne 20. 11.2015. 
Když si madarská vláda myslela, že problém vyřeší postavením prakticky nepropustného plotu, řekl papež v poselství $k$ 28. mezinárodnímu mírovému setkání katolického společenství Sant'Egidio v Tiraně: „Násilí je i stavět zdi a bariéry, abychom zastavili ty, kteří hledají místo v míru.“ A ještě dodal: „A násilí je i zatlačovat zpět lidi, kteří prchají před nelidskými podmínkami v naději na lepší budoucnost. ${ }^{(42}$

Opce pro uprchlíky neznamená, že by se papež zastával nekontrolovatelného př́íchodu uprchlíků. Neznamená to ani, že by měli migranti automaticky získávat právo na azyl. Účinné kontroly na hranicích a důkladné přezkoumání žádostí o azyl jsou úkoly jednotlivých států a jejich společenství, jako je Evropská unie. Opce pro uprchlíky je však jasným vyznáváním důstojnosti těchto lidí. $S$ každým z nich je proto třeba podle toho jednat. Pro křestany je humanitární pomoc uprchlíkům prubíŕským kamenem jejich víry.

Mnozí lidé v západoevropských církevních obcích stojí za Františkem a vykládají důstojnost lidské osoby stejně důsledně jako on. Ve východoevropských církevních obcích je naproti tomu nadšení jak biskupů, tak kněží a také mezi laiky kvůli jeho orientaci na koncilní obraz člověka spíše zdrženlivý. V Evangelii gaudium píše: „Je mi milejší církev otlučená, zraněná a špinavá proto, že vyšla do ulic, než církev, která je nemocná svou uzavřeností a pohodlností, s níž lne ke svým jistotám. ${ }^{\text {“43 }}$ Varuje zároveň před uzavřeností „do struktur, které nám skýtají falešnou ochranu, do norem, které $\mathrm{z}$ nás činí nelítostné soudce, do zvyků, $\mathrm{v}$ nichž se cítíme klidně, zatímco venku je množství hladovějících a Ježíš nám bez ustání opakuje: ,Vy jim dejte jíst!‘ (Mk 6,37)“.44

Překlad: Mgr. Marta Rynešová

\title{
Obraz člověka v Gaudium et spes a jeho praktický výklad papežem Františkem
}

\begin{abstract}
Abstrakt
Článek nejprve shrnuje nejdůležitější výpovědi 1. kapitoly pastorální konstituce Gaudium et spes s názvem „Důstojnost lidské osoby“. Poté článek na tématu ateismu a náboženské svobody ukazuje, jak koncil sám zasazuje tento obraz člověka do svých pastoračních úvah, které jsou významné i pro přítomnost církve $v$ dnešní společnosti. Závěrem se článek věnuje praktickému výkladu koncilního obrazu člověka v naší době.
\end{abstract}

Klíčová slova: obraz člověka, Gaudium et spes, II. vatikánský koncil, papež František

\section{Kontakt na autora}

\section{Dr. János Wildmann}

H-7635 Pécs, Sólyom dülö 3

wildmann@t-online.hu 